5.

\title{
SUDBINE POLJAKA U SOVJETSKOM SAVEZU TIJEKOM DRUGOGA SVJETSKOG RATA \\ (SLUČAJEVI GUSTAWA HERLINGA- GRUDZIŃSKOG I JÓZEFA CZAPSKOG \\ - PRIPADNIKA KRUGA PARIŠKE KULTURE)
}

\section{Mateusz Sokulski}

UDK: $316.344 .32(=162.1)^{“ 1} 194 “$

Pregledni članak

Sažetak: U radu se prikazuje djelovanje pisca Gustawa Herlinga-Grudzińskog i slikara Józefa Czapskog, interniranih u Sovjetskom Savezu tijekom Drugoga svjetskog rata. Njihove sudbine uspoređene su s općim iskustvima Poljaka podvrgnutih sovjetskim represijama. Gustaw Herling-Grudziński zarobljen je u pokušaju bijega na Zapad, odnosno prelaska sovjetsko-litvanske granice 1940. godine. Dvije godine proveo je u zatvorima i logoru u Jercevu. Józef Czapski, zarobljen je u rujnu 1939. te odveden u logor u Starobielsku. Bio je među malobrojnim zatočenicima koji su uspjeli izbjeći smrt kada su Sovjeti pobili više od dvadeset tisuća časnika u travnju 1940. s ciljem uništenja poljske elite (zločin u Katinu). Obojica su se priključila Poljskoj armiji generala Andersa, formiranoj 1941. godine, koja je preko Bliskog istoka stigla u Europu i borila se za oslobođenje Italije 1944. godine. Czapski i Herling-Grudziński sudjelovali su nakon rata u stvaranju Kulture, najznačajnijeg časopisa među poljskom političkom emigracijom.

Ključne riječi: Sovjetski Savez, Poljaci, logori, Katin, represije, robija

Gajni sporazum ministara vanjskih poslova Njemačke i Sovjetskog Saveza Joachima von Ribbentropa i Vjačeslava Molotova, potpisan 23. kolovoza 1939. godine, bio je temelj za ostvarivanje planova obiju sila spram Poljske. Nakon ugovora uslijedila je agresija spomenutih država na Poljsku - njemačka ju je vojska napala 1. rujna 1939., a sovjetska 17. rujna 1939. godine. Zbog ulaska sovjetskih trupa vlasti su donijele odluku o nuždi evakuacije vlastitih postrojbi u savezničku Rumunjsku. U situaciji neizbježnog pada Poljske, unatoč otporu i još uvijek nezavršenim borbama, već 28 . rujna 1939. godine došlo je do 
potpisivanja sovjetsko-njemačkog „ugovora o granici i prijateljstvu”. ${ }^{1}$ Pod kontrolom SSSRa našlo se $194 \mathrm{~km}^{2}$, s 12,5 milijuna stanovnika. Već 1 . listopada 1940. Politbiro Centralnog komiteta Svesavezne komunističke partije (boljševika) razradio je planove upravljanja osvojenim zemljama. ${ }^{2}$ Sovjetska propaganda predstavljala je svoj čin kao „oslobođenje” ovih krajeva. Brzo su bili formirani lokalni organi vlasti, koji su krajem listopada odobrili pripajanje ovih dijelova Sovjetskom Savezu, odnosno Bjeloruskoj Sovjetskoj Socijalističkoj Republici (BSSR) i Ukrajinskoj Sovjetskoj Socijalističkoj Republici (USSR). Vrhovno Vijeće SSSR-a, kao i Vrhovno Vijeće BSSR-e i USSR-e potvrdili su ove odluke. Stanovništtvu je dodijeljeno sovjetsko državljanstvo, a do kraja 1939. godine državno-političko uređenje izjednačeno je onome u ostalim dijelovima SSSR-a. ${ }^{3}$

Bitan element politike Moskve prema istočnim dijelovima prijeratne Poljske (tzv. Kresy) bio je teror, koji je služio kao instrument zastrašivanja u procesu zamišljene duboke promjene društvene svijesti u sklopu procesa sovjetizacije. Grupe NKVD-a, djelujući u suradnji sa Crvenom armijom, imale su popise navodnih neprijatelja komunizma. Do kraja 1939. godine uhićeno je 20 tisuća ljudi, a do lipnja 1941. 120 tisuća. Najžešće represije bile su usmjerene prema ljudima koji su činili prijeratni državni aparat u Poljskoj, dakle prema onima koji su pripadali političkoj ili društvenoj eliti. Među pripadnicima vojske zatočenih bilo je više od 200 tisuća ljudi, od kojih su tek malobrojni pušteni na slobodu prije srpnja 1941. Veliki broj interniran je u radnim logorima u Ukrajini i Bjelorusiji, a još veći je transportiran u logore u unutrašnjosti SSSR-a. ${ }^{4}$

U ožujku 1940. godine šef NKVD-a Lavrentij Berija u pismu Staljinu predložio je ubojstvo zatočenih časnika poljske vojske, jer su, kako je smatrao, činili opasnost za sovjetsku vlast. 15 tisuća zarobljenih u logorima u Starobjelsku, Ostaškovu i Kozjelsku kao i 6 tisuća iz zatvora u Ukrajini i Bjelorusiji - svi muškarci uz izuzetak jedne žene - bili su pobijeni u travnju 1940. godine. Među ubijenima su bili veterani poljsko-boljševičkog rata 1919.1920., časnici, policajci, svećenici raznih vjeroispovijesti, liječnici, znanstvenici itd. Najveći broj strijeljan je u Katinu. Tamo je ubijeno 10 tisuća ljudi iz kozjelskog logora. ${ }^{5}$

Drugi karakterističan element sovjetske politike terora bila su masovna iseljenja osoba koje je Kremlj smatrao „neprijateljima sistema”. Ova akcija izvedena je u četiri vala, od veljače 1940. do svibnja/lipnja 1941. godine i obuhvatila je gotovo 400 tisuća građana prijeratne Poljske. ${ }^{6}$

Sudbina zatočenih Poljaka promijenila se u srpnju 1941. godine, nakon izbijanja sovjetsko-njemačkog rata 22. lipnja 1941. godine. Naime, 30. srpnja iste godine u Londonu je pod pritiskom Velike Britanije potpisan ugovor o uspostavljanju poljsko-sovjetskih diplomatskih odnosa te o suradnji u borbi protiv Hitlerove Njemačke. Potpisali su ga premijer poljske vlade u Londonu Sikorski i veleposlanik SSSR-a u Velikoj Britaniji Ivan Majski. U dodatnom protokolu ugovora našla se i potvrda amnestije za sve građane Poljske deportirane u SSSR. Vojni Ugovor potpisan 14. kolovoza 1941. odnosio se na vojnu suradnju te je potvrdio formiranje Poljske armije u SSSR-u. Na njezino je čelo stao general Władysław

Andrzej PACZKOWSKI, Pót wieku historii Polski 1939-1989, Warszawa 1996., 18.-19.; Timothy SNYDER, Skrwawione ziemie. Europa między Hitlerem a Stalinem, Warszawa 2011., 149.

Stanisław CIESIELSKI - Grzegorz HRYCIUK - Aleksander SREBRAKOWSKI, Masowe deportacje ludności w Związku Radzieckim, Toruń 2003., 206.

Isto, 206.-207.; T. SNYDER, $n . d j .$, 145.-146.; A. PACZKOWSKI, $n . d j ., 20$.

A. PACZKOWSKI, $n$. dj., 24.-25.; S. CIESIELSKI - G. HRYCIUK - A. SREBRAKOWSKI, $n$. dj., 207.-208.

A. PACZKOWSKI, $n . d j$., 25.; T. SNYDER, $n$. $d j$., 146.-147., 157.-162.

S. CIESIELSKI - G. HRYCIUK - A. SREBRAKOWSKI, $n$. dj., 208.- 248. 
Anders, dotadašnji zarobljenik u Lubjanki.7 Gustaw Herling-Grudziński konstatirao je: „Ova je Poljska armija generala Andersa bila zapravo vojska zarobljenika, koju je i osnovao zarobljenik". ${ }^{8}$ Sovjeti su sprječavali odlazak iz logora mnogih zarobljenika koji nisu dobili informacije o amnestiji. Kod formiranja Andersove armije bitno je spomenuti da se radilo ne samo o formiranju vojske, nego prije svega o spašavanju što većeg broja ljudi zarobljenih u SSSR-u, između ostalog djece, žena, staraca interniranih u logorima i zatvorima. S druge strane, poljske vlasti u Londonu radile su na jačanju poljskih vojnih snaga na Zapadu, što su pozdravili Britanci, imajući u vidu kompliciran vojni položaj Saveznika na Bliskom istoku te u Sjevernoj Africi. ${ }^{9}$ Nakon što su amnestirani okupljeni, u dva je navrata (ožujak/ travanj 1942. i kolovoz 1942.) evakuirano između 110.000 i 115.000 ljudi. $^{10}$ Prema podacima Veleposlanstva Republike Poljske u SSSR-u, na sovjetskom teritoriju ostalo je još oko 680 tisuća građana Poljske, koji su postali žrtve sve lošijih odnosa poljske vlade u Londonu i Moskve u narednom razdoblju. ${ }^{11}$

Na konferencijama u Teheranu (28. studenoga - 1. prosinca 1943.) i Jalti (4. - 11. veljače 1945.) potvrđena je promjena granica Poljske. Ovom odlukom istočni dijelovi prijeratne Poljske pripojeni su SSSR-u. Tzv. Curzonova linija postala je tada granica između Poljske i SSSR-a. Konferencija na Krimu faktički je priznavala sovjetsku dominaciju nad Poljskom. ${ }^{12}$

Ovakav ishod međunarodnih ugovora izazvao je odluku većine političke i društvene elite kao i poljskih vojnika koji su se nakon završetka rata našli na Zapadu, između ostalog II. Andersovog korpusa, o ostanku u emigraciji. Fenomen ove emigracije očitovao se u tome što su „ne izlazeći iz kuće” na Zapadu, u trenutku odbijanja mogućnosti povratka u komunističku Poljsku, postajali emigranti. Procjenjuje se da je poslijeratna emigracija brojila između 500 i 600 tisuća ljudi. $^{13}$

Sudbine Poljaka u SSSR-u zarobljenih 1939./1940. godine koji su se priključili Andersovoj armiji 1941. godine dijelila su dvojica intelektualaca: Józef Czapski (1896.-1993.) i Gustaw Herling-Grudziński (1919.-2000.). Czapski se rodio 1896. godine u Pragu u palači Thun. Podrijetlom je bio iz aristokratske obitelji poljskih, austrijskih, njemačkih i ruskih korijena. Želio je postati slikar, zanimao se za glazbu, bio je vrhunski poznavatelj ruske književnosti, a njegovi su ukućani osim poljskog govorili i njemački i francuski jezik. ${ }^{14}$ Prilikom izbijanja Prvoga svjetskog rata stupio je u rusku carsku armiju. U srpnju 1917. godine, na večeri kod prijatelja, sreo je kneza Lvova, premijera privremene vlade koji je ustupio mjesto Aleksandru Kerenskom. Czapski je tvrdio da su komunisti jedina politički organizirana snaga, što je Lvov energično odbacivao, podcjenjujući snagu boljševika. Czapski je bio svjedok boljševič-

A. PACZKOWSKI, $n$. dj, 66., 97.; Piotr ŻAROŃ, Armia Andersa, Toruń 1997., 30.-31., 35.-39.

8 Gustaw HERLING-GRUDZIŃSKI - Włodzimierz BOLECKI, Rozmowy w Dragonei, Warszawa 1997., 95. Svi citati koje navodim vlastitog su prijevoda.

A. PACZKOWSKI, $n . d j ., 98 .-100$.

$10 \quad$ P. ŻAROŃ, $n$. dj., 118.-120., 140.-144., Andrzej PACZKOWSKI, $n . d j ., 100$.

11 19. siječnja 1943. godine vlada SSSR priopćila je da smatra sovjetskim državljanima sve građane krajeva anektiranih 1939. godine, Poljake također. Na taj način mogle su se naslutiti Staljinove namjere prema istočnim dijelovima prijeratne Poljske koje je SSSR zauzeo 1939. godine. Kada su u travnju 1943. godine Nijemci pronašli grobnice pobijenih u Katinskoj šumi i za to optužili sovjete, Sikroski je uputio Crvenom križu pismo s molbom da istraži taj slučaj. Kremlj je krajem travnja 1943. godine odlučio prekinuti odnose s vlastima u Londonu. Vidi: A. PACZKOWSKI, $n$. dj., 101.-103.

12 A. PACZKOWSKI, $n$. dj., 110., 137.-139.

13 Dariusz STOLA, „Uwagi o powojennej emigracji politycznej (1945-1947)”, Warszawa nad Tamiza, (ur. Andrzej Friszke), Warszawa 1994., 11.-12.

14 Wojciech KARPIŃSKI, Portret Czapskiego, Wrocław 1996., 5.-6., 92.-93. 


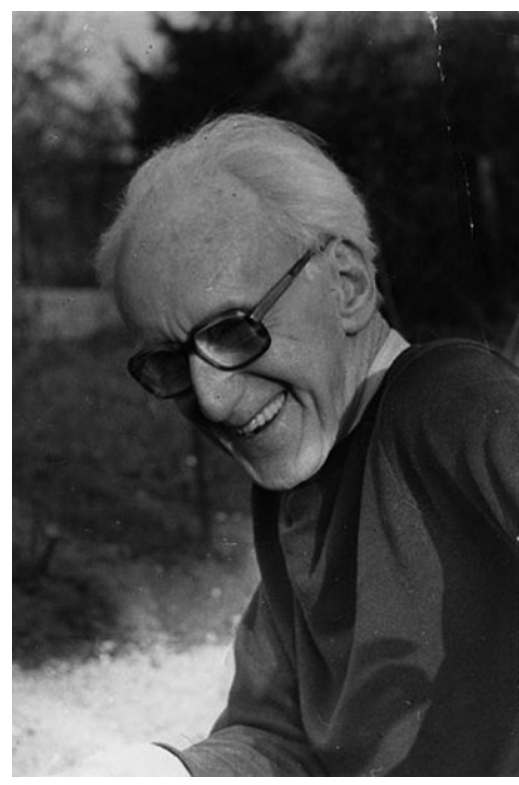

Slika 1. Józef Czapski u godinama nakon Drugoga svjetskog rata

kog prevrata. Pacifističko uvjerenje koje je proizlazilo iz Tolstojeve filozofije nesuprotstavljanja zlu, zamijenilo je odbijanje pasivnosti u situaciji sveobuhvatnog zla u obli$\mathrm{ku}$ boljševizma. Sudjelovao je u poljsko-boljševičkom ratu 1919.-1920. godine, ističući se hrabrošću. Nakon rata upisao je u Krakovu Akademiju likovnih umjetnosti. Godine 1923. s prijateljima je osnovao grupu zvanu Pariški komitet (Komitet Paryski). Njezine su članove nazivali kapistima. U Parizu, prijestolnici svjetske umjetnosti, boravio je od 1924. do 1930. godine. Czapskog je fascinirala francuska književnost, uglavnom Proust. Kako bilježi njegov prijatelj i biograf Wojciech Karpiński, njegovo pariško slikarstvo nije dobro poznato jer je propalo tijekom Drugoga svjetskog rata. Poznavajući njegovo tadašnje stvralaštvo, uspoređuje ga s ranim Matisseom ili čak njemačkim ekspresionistima. 1930. godine vratio se u Poljsku kao ugledna ličnost te je sve do 1939. godine aktivno sudjelovao u kulturnom životu. ${ }^{15}$

Drugi spomenuti intelektualac, Gustaw HerlingGrudziński, za generaciju je mlađi od Czapskog. Rodio se 20. svibnja 1919. godine u Kielcama. 1937. upisao je studij polonistike na Varšavskom sveučilišstu te je kao student vrlo aktivno počeo surađivati sa časopisima Nowa Kuźnia (Nova Kovačnica) i Kuźnia Młodych (Kovačnica mladih). Postao je urednik književnog dijela u dvotjedniku Przemiany (Pretvaranja), a uz to je pisao prikaze i članke. Godine 1938. postao je urednik u književnom dijelu časopisa Orka na ugorze (Oranje na ugaru). U to je vrijeme bio simpatizer mlade inteligencije nacionalne i socijalističke orijentacije. Pisao je o stvaralaštvu Gombrowicza i Miłosza. Herling-Grudziński zanimao se već tada za narodnu kulturu, koju nije podcjenjivao isključivo kao etnografsku pojavu, nego je u njoj prepoznavao izraz težnji nižih slojeva prema kulturnom napretku. ${ }^{16}$

Rat je zatekao oba pisca u različitim situacijama. Józef Czapski se odmah nakon izbijanja Drugoga svjetskoga rata prijavio u vojsku. Zarobljen je 27. rujna 1939. godine u Chmielu blizu Lavova. Bio je prebačen preko Lavova i Tarnopola u Sovjetski Savez do Voločiska odakle su ga odveli u Stariobjelsk ${ }^{17}$. Početkom listopada 1940. odveden je u Starobjelsku u zgradu bivšeg manastira pretvorenu u zatvor. U memoarima Na nieludzkiej ziemi (Na neljudskoj zemlji) prisjeća se polomljenih križeva i profaniranih vjerskih objekata. ${ }^{18}$ Opći pad morala, užasni uvjeti, a uz to hladnoća od -35 stupnjeva i glad dovodili su do stalnih svađa među poljskim časnicima. Usprkos tome, kao i stalnim pritiscima, Sovjeti nisu slomili zatočenike, uglavnom bivše vojnike iz poljsko-boljševičkog rata koji su u razdoblju Druge Poljske Republike činili elitu društva. Među njima su bili službenici, liječnici, katolički svećenici, rabin i svi su vodili žive razgovore. ${ }^{19}$

15 Isto, 7.-15.

16 Włodzimierz BOLECKI, „Inny świat” Gustawa Herlinga-Grudzińskiego, Warszawa 1994., 7., 11.-12., 14.; Zdzisław KUDELSKI, „Szkic do biogramu Gustawa Herlinga-Grudzińskiego”, Kresy. Kwartalnik literacki, 1/1991., br. 6, 31.

17 "Józef Czapski”, Wspótcześni polscy pisarze i badacze literatury. Stownik biobibliograficzny, (ur. Jadwiga Czachowska i Alicja Szałagan), knj. 2, Warszawa 1994., 85.-86.

18 Józef CZAPSKI, Na nieludzkiej ziemi, Kraków 2011., 9., 12.-16., 18.-21.

19 Isto, 20.-30. 
U memoarima Na nieludzkiej ziemi Czapski navodi kako su, ne obraćajući pozornost na zabranu, obilježili Dan neovisnosti Poljske - 11. studenoga. Pravo izbijanje patriotizma i osjećaja nade nastupilo je za vrijeme Božića, izazvano između ostalog primitkom pisama od najbližih. ${ }^{20}$ Atmosferu u logoru karakteriziralo je stalno prisluškivanje zatočenih te pokušaji podmićivanja i ucjenjivanja. O razlikama u shvaćanjima stvarnosti između Poljaka i Sovjeta, o čemu je pisao - pozivajući se na memoare Czapskog - Timothy Snyder, svjedoči situacija koju je slikar opisao u knjizi. Tijekom saslušanja pitali su ga što mu je prije polaska u Pariz 1924. godine rekao dužnosnik Ministarstva vanjskih poslova, budući da je „kao slikar, mogao (...) nacrtati plan grada”. ${ }^{21}$ Već od veljače 1940. počelo se pričati da će biti vraćeni kući. U travnju 1940. godine sovjetska ih je uprava u logoru uvjeravala da se radi upravo o tome. Od 3920 zatočenih u Starobjelsku ostalo je na kraju nekoliko desetaka. Prilikom formiranja Andersove armije 1941. godine otkriveno je da nedostaje oko 20 tisuća časnika zatočenih u tri logora. Czapski je 12. svibnja 1940. godine bio transportiran preko Smolenska na Istok. Tijekom puta vidio je u vlaku natpise na poljskom „iskrcali su nas kod Smolenska”. Czapski je na kraju stigao u zatočeništvo u Griazovcu kod Vologde, gdje je ostao sve do kolovoza 1941. Uvjeti su, kako spominje, bili su nešto bolji nego u Starobielsku. ${ }^{22}$ Tijekom zatočenja u nekoliko logora, prije svega u Griazovcu, Czapski je držao predavanja o francuskoj književnosti. Priznao je, da su doživljaji književnosti i umjetnosti bili za njega bijeg od strašne stvarnosti. ${ }^{23}$

Gustaw Herling-Grudziński se nakon evakuacije iz Varšave i kratkog boravka na obiteljskom imanju u Suchedniowu pokraj Kielca u listopadu 1939. godine uputio u Varšavu, gdje je sudjelovao u uspostavljanju organizacije pokreta otpora PLAN. ${ }^{24}$ Bio je šef stožera organizacije i urednik lista Biuletyn Polski (Poljski bilten) s nakladom od nekoliko stotina primjeraka. Htjeli su osnovati sličnu organizaciju u Lavovu i uspostaviti suradnju sa Zapadom. U prosincu 1940. Gustaw Herling-Grudziński je stigao u dio Poljske pod sovjetskom okupacijom, najprije u Białystok. Odatle je zbog nedostataka novca umjesto na Zapad preko Litve krenuo u Lavov, a nakon toga u Grodno. ${ }^{25}$ Prisjećao se boravka u Lavovu na početku rata. Uz pomoć profesora Kleinera i spisateljice Marije Dąbrowske, kao i Ostapa Ortwina, predsjednika Saveza književnika u Lavovu, koji još uvijek nije bio pod nadzorom Sovjeta, dobio je mogućnost boravka u tome gradu. Herling-Grudziński je vidio što se može dogoditi s poljskom inteligencijom koja je pod sovjetskom vlašću dijelom prihvatila sovjetsku ideologiju. Poslije boravka u Lavovu uputio se u Grodno, gdje je - da bi preživio - radio u Kazalištu lutaka. ${ }^{26} \mathrm{U}$ ožujku 1940. godine, prilikom pokušaja prelaska sovjetsko-litvanske granice, bio je prijavljen od strane švercera i priveden NKVD-u. Osuđen je na pet godina robije zbog tobožnjeg špijuniranja za Nijemce, o čemu je „svjedočilo” njegovo „njemačko” prezime. Od lipnja do studenog 1940. bio je u zatvorima u

\footnotetext{
Isto, 31.-32., 37.

Isto, 37., 39.-40.

Isto, $41 .-45$.

W. KARPIŃSKI, Portret Czapskiego, 18.-19.

PLAN - Polska Ludowa Akcja Niepodległościowa (Poljska narodna oslobodilačka akcija).

W. BOLECKI, „Inny świat” Gustawa Herlinga-Grudzińskiego, 15.-16.;„Gustaw Herling-Grudziński”, Wspótcześni polscy pisarze i badacze literatury. Stownik biobibliograficzny, (ur. Jadwiga Czachowska i Alicja Szałagan), knj. 3, Warszawa 1994., 238.; Z. KUDELSKI, n.dj., 32.-33.

26 G. HERLING-GRUDZIŃSKI - W. BOLECKI, Rozmowy w Dragonei, 122.-123.; Gustaw HERLINGGRUDZIŃSKI, Najkrótszy przewodnik po sobie samym, Kraków 2000., 34.-37.; W. BOLECKI, „Inny świat” Gustawa Herlinga-Grudzińskiego, 17.; Z. KUDELSKI, n.dj., 33.
} 
Vitebsku, Leningradu i Vologdi, da bi u studenom 1940. godine bio odveden u logor u Jercevu blizu Arhangelska, na samom sjeveru europskog dijela SSSR-a. Iskustva nakon uhićenja od strane NKVD-a, boravke u zatvorima i logoru opisao je u knjizi Inny świat. Zapiski sowieckie (Drugi svijet. Sovjetski zapisi) te djelomično i u dnevniku pod nazivom Dziennik pisany noca (Dnevnik pisan noću). ${ }^{27}$

Roman Inny świat, kako naglašavaju sam pisac i književni kritičari, nije samo memoarski zapis. ${ }^{28}$ Književni kritičar Tomasz Burek navodi da su činjenice koje pisac predstavlja u knjizi ispunjene unutarnjom vizijom pisca te na taj način dolazi do književne kreacije. ${ }^{29}$ Autor je priznao u razgovoru s književnim kritičarom Włodzimierzom Boleckim da su - iako su svi prikazani događaji i ljudi autentični - neka zbivanja i osobe za potrebe književnog opusa „blago upotpunjeni" da bi dobili književni karakter i da bi mogli najpotpunije izraziti logorsku stvarnost. $^{30}$

Kako navodi u knjizi Inny Świat, tijekom istrage nije se ponašao savršeno. U razgovoru s književnim kritičarom Boleckim pojasnio je da nije učinio ništa loše - nije bio ni slomljen, niti je koga prijavio, izdao, ali je imao trenutaka slabosti kada je osjećao strah. Tijekom zatočeništva u zatvoru u Grodnu bio je poslan na tri dana u samicu, gdje je u maloj ćeliji provodio vrijeme sa štakorima, u vodi do koljena. Ne mogavši spavati, čak ni nasloniti se na zid, trudio se ne onesvijestiti se, da se ne bi udavio u vodi. Maltretiranje i premlaćivanje bili su svakodnevnica u zatvoru. Optužbe zbog pokušaja bijega u inozemstvo i ilegalnog prelaska preko granice tumačio je željom za borbom protiv Nijemaca. Čuo je samo odgovor istražnog suca: „Ne trebamo ovakve saveznike!"31

Inny Świat je prije svega knjiga o ugroženim vrijednostima u totalitarnom svijetu i spašavanju tih vrijednosti. Gustaw Herling-Grudziński referira i na Josepha Conrada i njegovo shvaćanje časti i vjernosti. Knjiga prikazuje ljudsko zlo, barbarstvo, ali i trijezno analizira ljudski život. ${ }^{32}$ Istaknuti filozof i povjesničar Krzysztof Pomian dodaje da je piščevo stvaralaštvo potraga za odgovorima „kako živjeti u totalitarnom svijetu”, „kako se ponašati u njemu”. ${ }^{33}$ Gustaw Herling-Grudziński prikazuje mehanizme koji su funkcionirali u tom „drugačijem svijetu”. Urci i tzv. bezprizorni (mladi prijestupnici, koji još nisu navršili osamnaest godina) čine, kako kaže autor, „najopasniju polulegalnu mafiju u Rusiji, organiziranu po uzoru na masonske lože". Urci su bili obični kriminalci, no tek su s vremenom, nakon višekratnog zatočenja u logorima, mogli steći „autoritet”. Njihova je pozicija svjedočila o tome koliko su dugo bili u logorima, koliko su stekli krađama i ubojstvima političkih zatvorenika. Njihov utjecaj u logoru mogao se usporediti samo s utjecajem logorske uprave. ${ }^{34}$

27 „Gustaw Herling-Grudziński”, Literatura polska. Encyklopedia PWN, (ur. Sławomir Żurawski), Warszawa 2007., 251.; „Gustaw Herling-Grudziński”, Wspótcześni polscy pisarze i badacze literatury. Stownik biobibliograficzny, 238.; Gustaw HERLING-GRUDZIŃSKI, Inny świat. Zapiski sowieckie, Warszawa 1989., 11.-14., 20., 32.; W. BOLECKI, „Inny świat" Gustawa Herlinga-Grudzińskiego,18.-19.; Z, KUDELSKI, n.dj., 33.

28 Vidi predgovor pisca: G. HERLING-GRUDZIŃSKI, Inny Świat. Zapiski sowieckie, 7.-8.; Tomasz BUREK, „Cały ten okropny świat. Sztuka pamięci a zapiski w Innym Świecie Gustawa Herlinga-Grudzińskiego”, Gustaw HerlingGrudziński i krytycy. Antologia tekstów, (ur. Z. Kudelski), Lublin 1997., 214.

29 Tomasz BUREK, „Cały ten okropny świat. Sztuka pamięci a zapiski w Innym Świecie Gustawa Herlinga-Grudzińskiego", 214.

30 G. HERLING-GRUDZIŃSKI - W. BOLECKI, Rozmowy w Dragonei, 131.-133.

31 Isto, 125., 127.

32 Wojciech KARPIŃSKI, „Proza Herlinga-Grudzińskiego”, Gustaw Herling-Grudziński i krytycy. Antologia tekstów, Lublin 1997., 22.-23.

33 Krzystof POMIAN, „Herling- Grudziński- emigracja heroiczna”, Gustaw Herling-Grudziński i krytycy. Antologia tekstów, Lublin 1997., 31.

34 G. HERLING-GRUDZIŃSKI, Inny Świat. Zapiski sowieckie, 14., 23.-24. 
Kao ključ za shvaćanje mehanizma totalitarnog režima SSSR-a pisac koristi izraz koji je upotrijebila Nadežda Mandeljštam u svojim memoarima - zatvorska civilizacija (tjuremnaja civilizacija). Ona je po njegovom mišljenju bila karakteristična za SSSR. Na taj način nastalo je društvo za koje su zatvor, logor i robija postali modus egzistencije. Upravo po tome razlikuje Rusiju 19. stoljeća i SSSR. Navodi da je ono što je opisao Dostojevski bila patnja koja ipak nije imala genocidan karakter. Politika SSSR-a težila je k uništenju zatvorenika jer su uvjeti života, rada i ishrane bili ispod svakog minimuma. Samo su pojedinci uspijevali spasiti glavu. ${ }^{35}$ Gustaw Herling-Grudziński referira na knjigu Dostojevskog Zapisi iz mrtvog doma, navodeći:

Neusporediva su iskustava logora i robije. Spomenuo sam da su zatočenici tijekom robije proživljavali različite patnje, najveće su, kako se vidi u knjizi Dostojevskog, bile vezane uz okove, ali niti su oni bili gladni niti su ubijani radom kao sovjetski. ${ }^{36}$

Gustaw Herling-Grudziński navodi konkretne primjere pišući o ljudskom ponašanju u logorima. Inny Świat ocjenjuje kao pokušaj otkrivanja psihičkih poremećaja ljudi koji na prvi pogled djeluju normalno, ali koji su zarobljeni mehanizmima „drugačijeg svijeta” u totalitarnom sustavu. Knjiga je riznica uvida o psihopatologiji čovjeka. ${ }^{37}$ Mehanizam represije nije bio po riječima Herlinga-Grudzińskog usmjeren ka kažnjavanju, nego ka fizičkoj eksploataciji te potpunom preobražaju ličnosti. ${ }^{38}$ Kako kaže Włodzimierz Bolecki, u knjizi Inny świat opisano je postupni gubitak duše u logorskom sustavu: „Najprije putovnica, osobne stvari, poslije pamćenje, viđenje, nada.” Ovu svoju misao pisac je potkrijepio slučajem zatvorenika i poznatog pisca Šalamova, koji je u razgovoru sa svojim istražiteljem rekao da „sve može dati, no dušu nikada”. ${ }^{39}$ Herling-Grudziński je u razgovoru s Boleckim rekao da se tek jedan posto zatočenika uspio oduprijeti totalitarnom poretku, a većina takovih bili su vjernici. ${ }^{40}$

Ključem za razumijevanje Herlingovog iskustva u logoru filozofkinja Barbara Skarga, koja je i sama bila zatočena deset godina, smatra epilog knjige Inny świat. U lipnju 1945. godine autor je u Rimu, u - kako kaže Skarga - „našem svijetu”, sreo čovjeka s kojim je bio u Jercevu, starog poljskog komunista. Čovjek mu je priznao da je krivo optužio nekoliko Nijemaca koji su poslije toga bili ubijeni, a on sam je zahvaljujući tome spasio glavu. Molio je za razumijevanje, što bi podrazumijevalo i oproštaj. Herling nije ništa rekao, što Skarga tumači na ovakav način:

Oproštaj nije bio moguć; oprostiti, to bi bilo isto što i vratiti se u onaj svijet, priznati njegovo pravo na postojanje, opravdati ono što nije moglo biti opravdano te odbaciti sadašnji, ponovno rođeni život. (...) Nema oproštaja za svijet u kojem je sve naopako. (...) Izdaja je tamo svakodnevnica, časnost nešto rijetko, sramota na svakom koraku, smrt - svagdašnji kruh, a kruh teško dostupno blago. (...) To je svijet naopakog Dekaloga. Evo na čemu se zasniva njegova različitost. ${ }^{41}$

\footnotetext{
G. HERLING-GRUDZIŃSKI - W. BOLECKI, Rozmowy w Dragonei, 112.-114.

Isto, 112 .

7 Jan BIELATOWICZ, „Znak krzyża w martwym domu”, Gustaw Herling-Grudziński i krytycy. Antologia tekstów, (ur. Z. Kudelski), Lublin 1997., 196.-197.

38 G. HERLING-GRUDZIŃSKI, Inny Świat. Zapiski sowieckie, 91.

39 G. HERLING-GRUDZIŃSKI - W. BOLECKI, Rozmowy w Dragonei, 145.

40 Isto, 111.

41 Barbara SKARGA, „Świadectwo Innego Świata”, Gustaw Herling-Grudziński i krytycy. Antologia tekstów, (ur. Z. Kudelski), Lublin 1997., 203.
} 


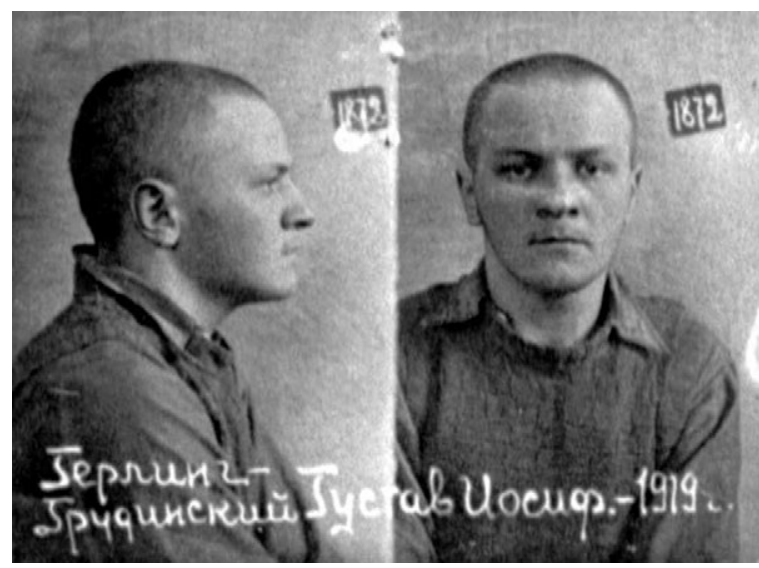

Slika 2. Gustaw Herling-Grudziński u sovjetskom zatočeništvu
Ugovor Sikorski-Majski iz ljeta 1941. godine omogućio je puštanje na slobodu Poljaka zatočenih u logorima i zatvorima te preseljenih u SSSR. Czapski se sjeća da je nakon dvije godine zatočeništva u Griazovac među njih došao general Anders, koji je i sam ranije bio zatočen u Moskvi, da bi po naredbi premijera Sikorskog formirao Poljsku armiju u SSSR-u. Rekao je bez imalo dvosmislenosti da se sad kao saveznici moraju boriti zajedno sa Sovjetima protiv nacističke Njemačke. ${ }^{42}$ Czapski je zapamtio opću euforiju među Poljacima, koja je izbila usprkos ekstremnom siromaštvu, nestašici hrane, odjeće i obuće. ${ }^{43}$

General Anders povjerio je Czapskom dužnost u Komitetu skrbi. Morao je novačiti ljude u vojsku. Slikar je također radio s nesposobnima i ranjenima jer se radilo o spašavanju što većeg broja ljudi. Jedno od najvažnijih pitanja bila je sudbina zarobljenih u Kozjelsku, Ostaškovu i Starobjelsku. Išao je u zapovjedništvo poljske vojske u Buzuluk zajedno s Andersom i veleposlanikom Kotom da bi tamošnje Poljake spasio prije zime. ${ }^{44}$ U prvom broju časopisa Orzet Biaty (Bijeli orao), koji je izdavao II. korpus Poljske armije, Czapski je pisao o sudbini časnika zarobljenih s njime 1940. godine: „Svaki od nas, misleći o odsutnima, vidi druga lica očima srca. Toliko je puno onih koje čekamo, čekamo sa rastućom zabrinutošću”. ${ }^{5}$ Prijelaz iz 1941. na 1942. proveo je na putu Buzuluk-Moskva-Kujbišev. U prosincu 1941. godine u Buzuluku, Czapski je nazočio susretu Sikorskog, Andersa i zamjenika Ministarstva vanjskih poslova SSSR-a Andreja Višinskog. Nisu dobili odgovor na pitanje što se dogodilo sa zarobljenim časnicima. ${ }^{46}$ Tijekom tog sastanka general Anders je opunomoćio Czapskog za rješavanje pitanja zatočenih u Kozjelsku, Ostaškovu i Starobjelsku. Pokušavao je doći do vrhovnih vlasti SSSR-a, što je bilo vrlo teško jer je sovjetska vlada bila napustila Moskvu zbog bojazni od njemačkog prodora. Tako je lutao po različitim mjestima (Kujbiševu, Čkalovu) pokušavajući naći Beriju, kao i druge visoke službenike NKVD-a, primjerice, Leonida Reichmana ili pak maršala Žukova. ${ }^{47} \mathrm{Na}$ kraju je Czapski uspio stići do Moskve, zajedno sa britanskom vojnom misijom. Sreo je Reichmana, koji mu je odmah odgovorio da ne zna za sudbinu časnika ${ }^{48}$. Czapski je shvatio da se radilo jedino o pokušaju da ga se omete. Još prije polaska u Moskvu, kako je priznao, posumnjao je da su Sovjeti mogli ubiti dvadeset tisuća ljudi. ${ }^{49}$

\footnotetext{
J. CZAPSKI, Na nieludzkiej ziemi, 51.-54.

Isto, 54.-67., 70 .

4 J. CZAPSKI, Na nieludzkiej ziemi, 70.-77., 87.-92.

ISTI, „Nieobecni”, Orzet Biaty. Polska walcząca na Wschodzie, 1/1941., br. 1, 3.

ISTI, Na nieludzkiej ziemi, 101.-104.

Isto, 137.-147.

48 Leonid Reichman, glavni istražitelj NKVD-a i voditelj Poljskog ureda u NKVD-u. (nap. ur.)

49 J. CZAPSKI, Na nieludzkiej ziemi, 156.-168., 173.-178., 181.-182.
} 
Sudbina Gustawa Herlinga-Grudzińskog poslije napada Njemačke na SSSR bila je kompliciranija nego sudbina Czapskog jer su mu logorske vlasti onemogućavale oslobođenje. Bio je premješten u novostvorenu 57. brigadu. Od 22. lipnja do kolovoza 1941. godine položaj Poljaka promijenio se iz temelja:

Prije izbijanja rusko-njemačkoga rata smatrali su nas 'antinjemačkim fašistima' i kukavicama, od kraja lipnja do kraja srpnja pronjemačkim fašistima i ne baš ovakvim kukavicama, u prvim danima kolovoza borcima za slobodu i saveznicima..$^{50}$

Sjeća se i da su svi zatočenici koji nisu bili poljske nacionalnosti odvojeni od Poljaka i da su se bojali da će Poljaci, sad kao saveznici Kremlja, surađivati s vlastima SSSR-a između ostaloga i na očuvanju sustava logora i zatvora.

Zadržavanje Herling-Grudzińskog bilo je potaknuto, kako se ispostavilo, objedama armenskog inženjera Mahepatiana, zarobljenog s Herlingom. O njemu je pisac govorio: „(...) bio mi je prijatelj bliži nego brat". Mahepatian ga je prijavio kao

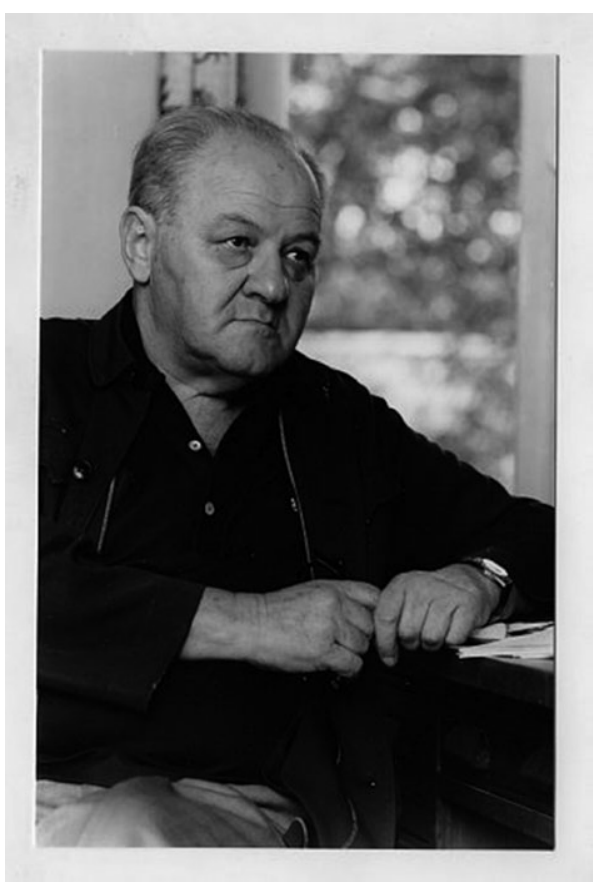

Slika 3. Gustaw Herling-Grudziński u godinama nakon Drugoga svjetskog rata tobožnjeg suradnika Józefa Becka, prijeratnog poljskog ministra vanjskih poslova te je u istrazi sugerirao da bi bilo bolje premjestiti ga u Moskvu i namjestiti mu proces s optužbom za špijunažu. ${ }^{51}$

U studenome 1941. godine, jako bolestan i bez nade da će u takvim uvjetima preživjeti dulje od nekoliko mjeseci, odlučio se za štrajk glađu, zahtijevajući da bude pušten na slobodu. Kasnije je rekao da je to bio više čin iz očaja nego iz hrabrosti. Bio je svjestan da se u vrijeme rata štrajk glađu može smatrati sabotažom. Unatoč tome, nije se htio predati bez borbe. Zajedno s četvoricom Poljaka koji su ostali u Jercevu počeo se boriti 30. studenoga. ${ }^{52}$ Jedina nada za njih bila je vjera da će ih ugovor Sikorski-Majski staviti iznad zakona totalitarnog režima. ${ }^{53}$ Spasio ga je poljski liječnik Zabielski te je poslije 8 dana gladi prebačen u tzv. „kosturnicu” - mjesto za zatvorenike nesposobne za rad. ${ }^{54}$

Na slobodu je pušten 20. siječnja 1942. te se preko Vologde i Sverdlovska uputio prema Čeljabinsku, gdje se nalazila poljska vojna misija. Nakon dugog puta, 9. ožujka stigao je u mjesto Lugovoje u Kazahstanu, a već je 30. ožujka ukrcan na brod na Kaspijskom moru te je 2. travnja stigao u Pahlaviju na teritoriju Irana. ${ }^{55}$ Sjećao se da je nakon napuštanja logora

\footnotetext{
G. HERLING-GRUDZIŃSKI, Inny Świat. Zapiski sowieckie, 234.

Isto, 229., 234.-235., 246.-247., 252.

Isto, 249.-250.

Isto, 259.-260.

54 Isto, 273.-274.; Z. KUDELSKI, n. dj., 33.

55 Z. KUDELSKI, n. dj., 33.; W. BOLECKI, „Inny świat” Gustawa Herlinga-Grudzińskiego, 20.-21.
} 
kupio bilježnicu te je počeo pisati, no ništa od toga nije sačuvano. Bilo mu je bitno ono što je čuo u trenutku napuštanja logora od drugih zatočenika: „Ispričaj ono što smo doživjeli, i što si doživio zajedno sa nama."

Józef Czapski tek je početkom ožujka 1942. godine stigao do Poljske vojske, smještene u Jungu-Julu pokraj Taškenta. ${ }^{57}$ Anders je bio svjestan da Vojska nema uvjeta za obuku u SSSRu, a u situaciji sve većih pritisaka Kremlja, u Vojsku u Jungu-Jul počelo je stizati još više civila. Ljudi u očajnom zdravstvenom stanju, bez oružja, mogli su jedino biti topovsko meso. Anders je htio spasiti što više ljudi, ali i stvoriti organiziranu vojsku spremnu za borbe. ${ }^{58}$

Početkom travnja 1942. godine Anders je pozvao Czapskog te ga je imenovao šefom vojne propagande. ${ }^{59}$ Kako navodi Wojciech Karpiński, Czapski se odlikovao velikom organizacionom sposobnošću. Učio je djecu i mladež, bio je odgovoran za izdavaštvo - dnevnike, tjednike, knjige. ${ }^{60}$ Jerzy Giedroyć, ranije tajnik poljskog veleposlanstva u Rumunjskoj, sudionik borbi u Tobruku, sjeća se arhiva Drugog korpusa. Svaki čovjek koji je prolazio kroz njega bio je obvezan napisati svjedočenje o svojoj sudbini, tako je nastao tzv. Andersov arhiv, smješten u Stanfordu u SAD-u. S ovim se svjedočanstvima upoznao i Solženjicin. Bio je duboko potresen njihovim sadržajem. ${ }^{61}$

U svibnju, lipnju 1942. omča oko Vojske još se više sužavala. Staljin je zabranio daljnje proširivanje Vojske, a poljski službeni delegati su uhićeni. Ne dobivši pomoć od Engleza, Anders je odlučio u srpnju/kolovozu evakuirati Vojsku prema Iranu. Krajem kolovoza Czapski je stigao u Iran. ${ }^{62}$ Kako je kasnije priznao, u ono vrijeme nisu bili realisti. Smatrali su da će zapadne demokracije pobijediti, što će izazvati promjene u samom SSSR-u, a nisu razmišljali o tome da će Poljska pasti u sovjetske ruke. ${ }^{63}$

Tijekom puta Bliskim istokom prema Europi Czapski je u Iraku upoznao Jerzyja Giedroyća, koji je postao tajnik u Odsjeku za propagandu. Postali su bliski prijatelji. ${ }^{64}$ Također, na Bliskom istoku je počelo prijateljstvo Czapskog i Herlinga-Grudzińskog. Bivši zatočenik logora u Jercevu rekao je da se prijateljstvo sa Czapskim počelo učvršćivati zbog toga, što su slično gledali na problem komunizma u SSSR-u. ${ }^{65}$ Kako je konstatirao Gustaw Herling-Grudziński, u sjećanjima Poljaka koji su preživjeli iseljenje u SSSR sveprisutna je bila glorifikacija vlastitog naroda i ekskluzivizacija poljske patnje. Poljski bjegunci bili su uvjereni da je komunizam mogao zaživjeti jedino među Rusima, da je to njihov poredak koji su sami zaslužili. Nisu obraćali pozornost na tragičnu sudbinu Rusa, ignorirali su njihovu nesreću, dok su generala Andersa ocjenjivali kao Mojsija koji je njih Poljake vodio kao Mojsije Židove iz Egipta. ${ }^{66}$ Włodzimierz Bolecki je zaključio da je „(...) univerzalna, nadnacionalna perspektiva knjige Inny świat omogućila Herlingu uhvatiti najdublju srž komunističkog totalitarizma: nije uništavao narode, nego ljude (...)" ${ }^{67}$

\footnotetext{
G. HERLING-GRUDZIŃSKI - Włodzimierz BOLECKI, Rozmowy w Dragonei, 94.-96.

J. CZAPSKI, Na nieludzkiej ziemi, 203.-204.

Isto, 231.-232., 235.-236.

Isto, 233.-234.

W. KARPIŃSKI, Portret Czapskiego, 23.-24.

Jerzy GIEDROYĆ, Autobiografia na cztery ręce, Warszawa 1996., 99.-101.

J. CZAPSKI, Na nieludzkiej ziemi, 295.-300., 320.-325.

Isto, 338.-339.

J. GIEDROYĆ, Autobiografia na cztery ręce, 81.-82., 97.-98.

G. HERLING-GRUDZINSKI - Włodzimierz BOLECKI, Rozmowy w Dragonei, 124.

Isto, 109.-111.

W. BOLECKI, „Inny świat” Gustawa Herlinga-Grudzińskiego, 126.-127.
} 
Oba intelektualca također su iskustva stečena putovanjima po Bliskom istoku doživljavali mnogo drugačije nego većina Poljaka. Govoreći o Bliskom istoku Gustaw Herling-Grudziński se prisjeća fantastičnih gradova koje je uspio vidjeti tijekom puta II. korpusa prema Europi. Kao izuzetno zanimljive opisuje Jeruzalem, Bagdad, Mosul, a u Egiptu Aleksandiju i Aden, koji ga je najviše oduševio. ${ }^{68}$ Govoreći o doživljajima Poljaka u Iraku, Palestini, Czapski se sjetio razgovora s jednim pilotom u Bagdadu koji se želio vratiti u zavičaj te je rekao slikaru: „Dosta mi je ovih svjetova i pejzaža." ${ }^{69}$ Czapski priziva atmosferu od prije Drugog svjetskog rata, kad su on i mnogi drugi željeli posjetiti daleke zemlje. No, drugačije su razmišljali Poljaci iz istočnih dijelova prijeratne Poljske, privrženi svojoj domovini - gradićima, selima, livadama, šumama. Czapski navodi:

Mi koji smo maštali o putovanjima, egzotici, imali smo u nekim trenucima, usprkos tragičnim uvjetima, svoje doživljaje (...), no ovi ljudi, čija mašta nije prekoračivala horizont mjesta u kojima su se rodili, zemlju na kojoj su radili, odsječeni su od korijenja, lišeni su svega. ${ }^{70}$

U bilješci od 16. veljače 1943. prikazuje doživljaje iz Muzeja u Bagdadu. Skulpture i vaze iz doba Sumera bile su za njega prilika za razmišljanje o umjetnosti. Unatoč teškom položaju vojske i strašnom iskustvu, doživljaj sumerskih umjetnina izazvao je osjećaj divljenja bogatstvu cijele civilizacije od antike sve do suvremenog doba. ${ }^{71}$

U travnju 1943. u Iraku Poljaci su saznali za pronalazak masovnih grobnica u Katinskoj šumi. Nijemci su izvijestili o 10 tisuća leševa poljskih časnika, koje su otkrili tijekom rata sa SSSR-om. Sovjeti su iskoristili tu priliku za prekid odnosa s poljskom vladom u Londonu. Sami su proglasili u Moskvi buduću vladu poljskih komunista. Andersovi vojnici postali su svjesni da Zapad neće reagirati. Riječ Katin u Poljskoj ostala je simbol zataškanog zločina, opće poznatog u društvu, koji se do sloma komunizma nije smio spomenuti u javnom životu. ${ }^{72}$ Czapski je to doživljavao s ogorčenjem, o čemu je govorio 1983. godine prilikom objavljivanja knjige o Katinu u Bruxellesu. ${ }^{73}$ Autorica knjige Aleksandra Kwiatkowska-Viatteau istražila je tadašnji odnos svjetskih dužnosnika prema slučaju Katin. Nema sumnje da su Churchill kao i Roosevelt bili dobro informirani, no zbog interesa suradnje sa Sovjetima nisu htjeli o tome govoriti. ${ }^{74}$ Govoreći o Katinu, Herling u memoarima Dziennik pisany noca Herling prepričava svoj razgovor iz 1979. godine s profesorom sudske medicine Sveučilišta u Napulju Vincenzom Palmierijem, članom međunarodne komisije Crvenog križa koja je 1943. stigla u Katinsku šumu. Talijan je ispričao kako je nakon istrage bilo jasno da je zločin počinjen prije 3 godine, dakle prije napada Nijemaca na SSSR. Cak je brezova šuma koju su Sovjeti zasadili nad grobovima bila stara tri godine. Bez ikakve dvojbe rezultate istrage potpisalo je 12 osoba, no dvije - iz Sofije i Praga - otkazale su poslije 1945. godine svoj potpis. Liječnik je zaključio: „Možda bih i ja otkazao, da su sovjetske trupe oslobodile Napulj”, dodajući da ga „dan-danas (...) muči ova

\footnotetext{
G. HERLING-GRUDZIŃSKI, Najkrótszy przewodnik po sobie samym, 38.-39.

Józef CZAPSKI, „Artiem”, Rozproszone. Teksty z lat 1925-1988, Warszawa 2005., 109.

Isto, 109.-110.

ISTI, „Źródła nowoczesności”, Rozproszone. Teksty z lat 1925-1988, 86.

W. KARPIŃSKI, Portret Czapskiego, 24.-25.

Vidi: Aleksandra KWIATKOWSKA-VIATTEAU, Katyn. L'armee polonaise assassinee 1940-1943, Bruxelles 1983.

J. CZAPSKI, „Katyń”, Rozproszone. Teksty z lat 1925-1988, 436.-438.
} 
slika: poljski časnici na koljenima, zavezanih ruku, udarcem nogom bačeni u jamu poslije streljana u zatiljak." 75 Spomenuo je da je poslije rata bio podvrgnut ostracizmu među ljevičarskim elitama Napulja. ${ }^{76}$

U prosincu 1943. Gustaw Herling-Grudziński našao se u Tarentu, gdje je obolio od tifusa te je bio prebačen u vojnu bolnicu u Nocere, a nakon tri mjeseca u Sorente. Tamo je upoznao Benedetta Crocea kojem se divio još prije rata dok je čitao njegove radove. Njegovom se kćeri pisac oženio 1955. godine. Kao radiotelegrafist Herling-Grudziński se borio u bitci za Monte Cassino u svibnju 1944. godine. ${ }^{77}$ Još prije spomenute borbe, vojnici su bili svjesni da neće osvojiti ništa za Poljsku. Usprkos tome, nitko nije bio za povlačenje. Tijekom nekoliko godina vojnog školovanja na Bliskom istoku mnogo su slušali o njemačkim zločinima u Poljskoj pa su se željeli boriti protiv nacista. ${ }^{78} \mathrm{U}$ tekstu objavljenom u sklopu prve obljetnice bitke, Herling-Grudziński je obrazložio smisao poljskog angažmana kao prkos međunarodnom trgovanju budućom kartom Europe. Poljaci su željeli dokazati svoje pravo na slobodnu domovinu. Najveći dojam na pisca ostavilo je ponašanje generala Freyberga, zapovjednika novozelandske vojske, za vrijeme prve obljetnice bitke. Freyberg, zapovjednik vojske koja se herojski iskazala u borbama za Kretu, dugim salutiranjem odao je počast pred spomenikom palim Poljacima. ${ }^{79}$

Trideset godina kasnije, na godišnjicu bitke, Gustaw Herling-Grudziński govorio je o osjećaju ponosa zbog sudjelovanja u borbi, no ostao je i snažan osjećaj poraza zbog sudbine poslijeratne Poljske. ${ }^{80}$ Taj dojam nakon bitke na Monte Cassinu izrazio je i Czapski u tekstu objavljenom u časopisu Orzet Biaty u listopadu 1944. godine. Obratio se Jacquesu Maritainu i Françoisu Mauriacu ogorčeno komentirajući njihovu ravnodušnost po pitanju poljske katastrofe. ${ }^{81}$ Obojicu je upoznao tijekom studija u Parizu, a na njega su ostavili dojam nonkonformista. Czapski, govoreći o tragediji Varšave, potpuno uništene tijekom Varšavskog ustanka i s velikim žrtvama od 200.000, pitao se: „Zar doista nema nikog u ovim zemljama, tko bi htio vidjeti istinu, tko bi htio cijeniti vrijednost i stradanje druge zemlje, ako već nije u stanju pomoći?" 82 Postavio je pitanje gdje su sada pisci, intelektualci koji su uvijek, kao što je bilo u slučaju Dreyfusa, govorili „optužujem” i „,ne mogu šutjeti”. Gdje su Huxley, Sinclair Lewis, Dreiser, koji su uvijek bili angažirani? ${ }^{83}$

Nakon završetka talijanske kampanje Gustaw Herling-Grudziński je upućen u Rim, kamo su ga pozvali Jerzy Giedroyć i Józef Czapski. Pisac je postao glavni urednik književne rubrike u časopisu Orzet Biaty. Tada se i sprijateljio sa Jerzyjem Giedroyćom, kojeg opisuje kao osobu kojoj pripadaju velike zasluge za Poljsku. Kaže: „Teško je povjerovati kakve je velike stvari napravio ovaj neobičan čovjek." ${ }^{84}$ Czapski i Herling-Grudziński bili su među

\footnotetext{
Gustaw HERLING-GRUDZIŃSKI, Dziennik pisany noca 1973-1979, Warszawa 1995., 307.

Isto.

77 ISTI, Najkrótszy przewodnik po sobie samym, 40.-42.; Z. KUDELSKI, „Szkic do biogramu Gustawa Herlinga-Grudzińskiego”, 34.; W. BOLECKI, „Inny świat” Gustawa Herlinga- Grudzińskiego, 21.

78 G. HERLING-GRUDZIŃSKI, Najkrótszy przewodnik po sobie samym, 43.-44.

79 G. HERLING-GRUDZIŃSKI, „Karpacka swoim poległym”, Orzet Biaty. Polska walcząca na ziemi wtoskiej, 5/1945., br. 30(165), 5.

80 W. BOLECKI, „Inny świat” Gustawa Herlinga- Grudzińskiego, 22. Za: Dziennik pisany noca 1973-1979, bilješka od 18. 5.1974 .

81 Jacques Maritain (1882.-1973.), francuski katolički mislilac; François Mauriac (1885.-1970.), francuski pisac. (nap. ur.)

82 Józef CZAPSKI, „List otwarty do Jacques’a Maritaina i Francois Mauriaca”, Rozproszone. Teksty z lat 1925-1988, 87.-88., 90

83 Isto, 94.-95.

84 G. HERLING-GRUDZIŃSKI, Najkrótszy przewodnik po sobie samym, 18.-19., 51.
} 
najzaslužnijima u stvaranju kruga Kulture, koji je izdavao i istoimeni časopis. Giedroyć je još potkraj rata razmišljao o pokretanju izdavačkog projekta. $\mathrm{Na}$ taj se način htio pripremiti za ono što je već tada predviđao: povlačenje zapadnog priznanja emigrantske poljske vlade u Londonu i nastavak dugog razdoblja emigracije. Nije vjerovao u sljedeći rat ili u povratak u domovinu, kao što je to bilo to uobičajeno među emigrantima. ${ }^{85}$ Književni institut osnovan je u Rimu u sklopu Poljske vojske. S obzirom na nužnost evakuacije vojske iz Italije, kako navodi Giedroyć, odlučili su se za odlazak u Pariz. ${ }^{86}$ Što se tiče odnosa prema zemljama Istočne Europe, Giedroyć se ponašao potpuno drukčije od londonske emigracije koja je htjela kreirati „Novu Poljsku” u emigraciji. Vjerovao je da se sudbina „malih” može promijeniti i da obični ljudi mogu drugačije oblikovati stvarnost. ${ }^{87}$ Radili su na pomirenju Poljaka s narodima Istočne Europe - Rusima, Litvancima, Ukrajincima. Prihvatili su granicu na Curzonovoj liniji, odbijajući sve moguće teritorijalne pretenzije prema Ukrajini, Bjelorusiji te Litvi jer su mogle postati kamen spoticanja i time spriječiti pomirenje. ${ }^{88}$

Iskustva sovjetskog totalitarizma imala su veliki utjecaj na oba intelektualca. Gustaw Herling-Grudziński stvarnost SSSR-a nazvao je „drugačijim svijetom” u kojem nema vrijednosti i principa koje je poznavao. Naglasio je da se našao u logoru već kao zreo čovjek od dvadeset godina. Uspio je zadržati nadu i vjeru u postojanje temeljnih ljudskih vrijednosti i načela te je zahvaljujući njima izdržao. ${ }^{89}$

Govoreći o životu poljskih iseljenika, Gustaw Herling-Grudziński u tekstu objavljenom u časopisu Orzet Biaty rekao je da je njihova sudbina bila teža od sudbine zatočenika u radnim logorima. U Jercevu je barem znao da će se prije nego što padne noć vratiti iz šume; imali su osiguran minimum egzistencije:

Sada sam potpuno siguran da je život ovih jadnih osoba nerijetko bio mnogo teži od organiziranog procesa postupnog umiranja u logorima i zatvorima..$^{90}$

U odnosu na druge Poljake podvrgnute represijama, Herling-Grudziński je bio lišen antiruskih uvjerenja. Sjeća se kako su mnogi poljski iseljenici i oni koji su imali iskustvo sovjetskih logora piscu zamjerali njegov pozitivan odnos prema Rusima. Pisac je međutim upamtio Ruse iz logora koji su se poput njega suprotstavili totalitarnom režimu logora i htjeli se držati vlastitih principa. ${ }^{91}$ U priči Inny Świat Grudziński prikazuje Rusiju ne kao problem Poljske i Moskve, nego kao univerzalni problem - logori nisu samo unutarnji problem SSSR-a nego i univerzalni problem. Problem Rusije, njezine samosvijesti i časti postao je stoga kulturološki problem. ${ }^{92}$

85 J. GIEDROYĆ, $n . d j ., 121 .-122$.

86 Isto, 123.-126., 130.; G. HERLING-GRUDZIŃSKI, Najkrótszy przewodnik po sobie samym, 53.-54.

87 Andrzej Stanisław KOWALCZYK, Od Bukaresztu do Laffitów. Jerzego Giedroycia rzeczpospolita epistolarna, Sejny 2006.,10.-11.; J. GIEDROYĆ, $n$. dj., 158.

88 J. GIEDROYĆ, $n$. dj., 153., 228. Vidi također pismo „Kulturi” svećenika Józefa Majewskog objavljeno u broju 11 1952. godine.

89 G. HERLING-GRUDZIŃSKI - Włodzimierz BOLECKI, Rozmowy w Dragonei, 127.-129.

90 G. HERLING-GRUDZIŃSKI, „Dokument literacki”, Orzęt Biaty. Polska walcząca na ziemi wtoskiej, 5/1945., br. 16(151), 7.

91 G. HERLING-GRUDZIŃSKI - Włodzimierz BOLECKI, Rozmowy w Dragonei, 109.-110.; W. BOLECKI, „Inny świat" Gustawa Herlinga- Grudzińskiego, 126.-127.

92 Leszek SZARUGA, „Szczerość i prawda”, Gustaw Herling-Grudziński i krytycy. Antologia tekstów, (ur. Z. Kudelski), 14.-15. 
Józef Czapski, pozivajući se na pjesmu Rodina iz 1917. godine, ovim je riječima okarakterizirao sovjetsku stvarnost: „Gledajući nadolazeći dan, od 1939. godine vidim samo smrt, logore, poniženog čovjeka" ${ }^{93} \mathrm{Ni}$ on kao ni Herling-Grudziński na svijet sovjetskog totalitarizma nije gledao kao na nešto tipično rusko. Prisjetio se svog boravka u Rusiji 1919. te godina provedenih u toj zemlji još prije boljševičke revolucije. Sjećao se straha koji je u potpunosti obuzeo ljude u totalitarnom SSSR-u, nitko ništa nije htio govoriti iz straha. Suprotstavljao je svoje doživljaje iz boljševičkog vremena carskoj Rusiji, gdje su - kako je navodio - čak i analfabeti razmišljali samostalno o ozbiljnim egzistencijalnim pitanjima. Poljaci se, tvrdio je, nisu prilagodili sovjetskom režimu. Spomenuo je razgovor s Anom Ahmatovom, čuvenom ruskom pjesnikinjom, u proljeće 1942. godine. Prevodio joj je poljsko pjesništvo tijekom spomenutog susreta u Srednjoj Aziji u Taškentu. Zaključila je: „Dakle, vi ste pronašli izražaj za ovo što ste doživjeli, a mi... još ništa". ${ }^{4}$

Govoreći o specifičnosti poljskih doživljaja sjeća se razgovora u Italiji sa ženom koju je poznavao još prije rata:

Nešto drugo nas međusobno jače povezuje - boravak u Rusiji između 1939. i 1942. Povezuje nas to, za mnoge ljude dosadno „slobodno zidarstvo” tzv. pravoslavnih koji su otišli iz Rusije. Ne mogu s drugima podijeliti srž svojih doživljaja jer za nas ta srž nije potpuno jasna, u njoj postoji „Srce tame”, do kraja neosviješteno, ali toliko snažno doživljeno da guši, odvaja od drugih ljudi, za koje je to još samo jedan čvor sjećanja, više ili manje jezovitih. ${ }^{95}$

Odnosi se to i na definiciju „drugačijeg svijeta” koju je Grudziński predstavio kao suprotnost stvarnosti iz razdoblja prije Drugoga svjetskoga rata. Svatko je prije početka rata znao nešto o SSSR-u. No tek kad su stigli onamo, počeli su otkrivati tu stvarnost: „Taj svijet koji je za neke svijet nepravde, robije i poništenja ljudskog dostojanstva, dok je za druge još uvijek svijet vjere i nade u budućnost". ${ }^{96}$

Govoreći o sudbini zatočenika u logorima i iseljenika, pozvao se na razgovor s bjeloruskim seljakom Artjomom koji je uspio preživjeti zatočeništvo u Kolimi gdje je smrtnost iznosila $70 \%$. Piše da je njegova osobna priča slična pričama tisućama drugih Poljaka, Ukrajinaca, Židova, Bjelorusa odsječenih od svoje male domovine kojoj su bili jako privrženi. O ovakvim doživljajima nitko ne želi niti čuti - piše s ogorčenjem Czapski misleći najvjerojatnije na pragmatizam zapadnih političara i fascinaciju komunizmom na Zapadu - jer se navodno radi o dokazima zaostalosti i kočenja razvoja najnovijeg tipa demokracije. ${ }^{97}$

\footnotetext{
J. CZAPSKI, Na nieludzkiej ziemi, 230.

Isto, 109., 186.-193., 251., 256.

Józef CZAPSKI, „Via Dei Fiori”, Rozproszone. Teksty z lat 1925-1988, Warszawa 2005., 117.

Isto, 117.-118.

ISTI, „Artiem”, Rozproszone. Teksty z lat 1925-1988, 110.-111.
} 


\section{The fates of Poles in the Soviet Union During WORLD WAR II \\ (The cases of Gustav Herling-Grudziński and JÓZEF CZAPSKI - MEMBERS OF THE CIRCLE AROUND THE Parisian KULTURA)}

The secret agreement between the foreign ministers of Germany and the Soviet Union, commonly known as the Molotov-Ribbentrop pact), was the prelude to both forces attacking Poland in September 1939. Despite the still ongoing clashes, the "Treaty of Friendship, Cooperation and Demarcation" between Germany and the Soviets was signed as early as September 28, 1939, acknowledging the partition of Poland by the occupying forces.

The rule of terror, directed especially against the pre-war elites of Poland, accompanied the implementation of the Soviet system in the Eastern regions of the Second Polish Republic (the so-called Kresy). Frequent deportations, arrests, internments in camps and executions were synonymous with these policies.

The already famous painter Józef Czapski, a veteran of the Polish-Soviet war of 1919-1921, and the talented literary critic Gustaw Herling-Grudziński fell victim to the terror.

Józef Czapski was captured in September 1939 and taken to the camp in Starobilsk. He was among the few prisoners who managed to escape death when, in April 1940, acting upon the orders of their highest authorities, Soviets killed more than 20 thousand Polish officers, with the ultimate goal of eradicating the Polish elites (the Katyn massacre).

After the war broke out, Herling- Grudziński joined the Polish People's Liberation Action (Polska Ludowa Akcja Niepodlegtościowa) in Warsaw. In late 1939 he travelled to the Soviet-occupied territories to help found a branch of this organization in Lvov. He was captured while trying to escape to the West in 1940 and spent the next two years in prison in Jercev. In 1941/1942, both men joined the Polish General Anders' Army, formed in 1941. In 1944, they arrived to Europe via the Middle East and joined the struggle for the liberation of Italy. After the war ended, Czpaski and HerlingGrudziński were among the co-founders of Kultura, the most significant magazine among the Polish political emigration. Their books, $A$ World Apart (Inny swiat), The Inhuman Land (Na nieludzkiej ziemi) and The Soviet Writings, are relevant as sources of information about communist totalitarianism.

Keywords: Soviet Union, Poles, camps, Katyn, repressions, lag

\section{$\cos$}

\section{Bibliografija}

\section{Novine i časopisi}

Józef CZAPSKI, „Nieobecni”, Orzet Biaty. Polska walcząca na Wschodzie, 1/1941., br. 1, 1.

Gustaw HERLING-GRUDZIŃSKI, „Dokument literacki”, Orzet Biaty. Polska walczaca na ziemi wtoskiej, 5/1945., br. 16 (151), 7.

Gustaw HERLING-GRUDZIŃSKI, „Karpacka swoim poległym”, Orzet Biaty. Polska walcząca na ziemi wtoskiej, 5/1945., br. 30 (165), 5. 


\section{Literatura}

Jan BIELATOWICZ, „Znak krzyża w martwym domu”, Gustaw Herling-Grudziński i krytycy. Antologia tekstów, (ur. Zdzisław Kudelski), Lublin 1997., 195.-198.

Włodzimierz BOLECKI, „Inny świat” Gustawa Herlinga-Grudzińskiego, Warszawa 1994.

Tomasz BUREK, „Cały ten okropny świat. Sztuka pamięci a zapiski w Innym Świecie Gustawa Herlinga-Grudzińskiego”, Gustaw Herling-Grudziński i krytycy. Antologia tekstów, (ur. Zdzisław Kudelski), Lublin 1997., 206.-214.

Stanisław CIESIELSKI - Grzegorz HRYCIUK - Aleksander SREBRAKOWSKI, Masowe deportacje ludności w Związku Radzieckim, Toruń 2003.

Józef CZAPSKI, Na nieludzkiej ziemi, Kraków 2011.

Józef CZAPSKI, Rozproszone. Teksty z lat 1925-1988, Warszawa 2005.

Jerzy GIEDROYĆ, Autobiografia na cztery ręce, Warszawa 1996.

Gustaw HERLING-GRUDZIŃSKI, Dziennik pisany nocq 1973-1979, Warszawa 1995.

Gustaw HERLING-GRUDZIŃSKI, Inny świat. Zapiski sowieckie, Warszawa 1989.

Gustaw HERLING-GRUDZIŃSKI, Najkrótszy przewodnik po sobie samym, Kraków 2000.

Gustaw HERLING-GRUDZIŃSKI - Włodzimierz BOLECKI, Rozmowy w Dragonei, Warszawa 1997.

Wojciech KARPIŃSKI, Portret Czapskiego, Wrocław 1996.

Wojciech KARPIŃSKI, „Proza Herlinga-Grudzińskiego”, Gustaw Herling-Grudziński i krytycy. Antologia tekstów, (ur. Zdzisław Kudelski), Lublin 1997., 22.-28.

Andrzej Stanisław KOWALCZYK, Od Bukaresztu do Laffitów. Jerzego Giedroycia rzeczpospolita epistolarna, Sejny 2006.

Zdzisław KUDELSKI (ur.), Gustaw Herling-Grudziński i krytycy. Antologia tekstów, Lublin 1997.

Zdzisław KUDELSKI, „Szkic do biogramu Gustawa Herlinga-Grudzińskiego”, Kresy. Kwartalnik literacki, 1/1991., br. 6, 30.-43.

Aleksandra KWIATKOWSKA-VIATTEAU, Katyn. L'armee polonaise assassinee 1940-1943, Bruxelles 1983.

Literatura polska. Encyklopedia PWN, (ur. Sławomir Żurawski), Warszawa 2007.

Andrzej PACZKOWSKI, Pót wieku historii Polski 1939-1989, Warszawa 1996.

Krzystof POMIAN, „Herling- Grudziński- emigracja heroiczna”, Gustaw Herling-Grudziński i krytycy. Antologia tekstów, (ur. Zdzisław Kudelski), Lublin 1997., 29.-32.

Barbara SKARGA, „Świadectwo Innego Świata”, Gustaw Herling-Grudziński i krytycy. Antologia tekstów, (ur. Zdzisław Kudelski), Lublin 1997., 199.-205.

Timothy SNYDER, Skrwawione ziemie. Europa między Hitlerem a Stalinem, Warszawa 2011.

Dariusz STOLA, „Uwagi o powojennej emigracji politycznej (1945-1947)”, Warszawa nad Tamiza, (ur. Andrzej Friszke), Warszawa 1994., 7.-18.

Leszek SZARUGA, „Szczerość i prawda”, Gustaw Herling-Grudziński i krytycy. Antologia tekstów, (ur. Zdzisław Kudelski), 12.-21.

Wspótczésni polscy pisarze i badacze literatury. Stownik biobibliograficzny, (ur. Jadwiga Czachowska i Alicja Szałagan), knj. 2-3, Warszawa 1994.

Piotr ŻAROŃ, Armia Andersa, Toruń 1997. 